\title{
Corporate Governance - A Broader Perspective
}

\author{
Dr. Prashant Kumar \\ [Principal (OSD), Department of Economics, Sri Aurobindo College (Eve.)/University of Delhi, India]
}

\begin{abstract}
In this paper it is argued that the notion of market-based corporate governance approach should be broadened to include the problem of owner-controlled firms and large block-holders and should be generalized to a model of multilateral negotiations and influence-seeking among a number of different stakeholders. In practice such a model should incorporate checks and balances between various stakeholders and outside constraints and must take into account how the political and legal system of a country affects this balance. In fact, even if there is theoretical reason to believe that ownership with its incumbent benefits and costs belongs to equity, this view is not dominant in most economies outside United Kingdom and United States of America. The broader notion of corporate governance offers hope for understanding better the developing economies in particular - and other economies in general - where anonymous stock markets are not likely to promote the necessary entrepreneurial activity and corporate restructuring. It suggests that other mechanisms, such as product market competition, peer pressure, or labor market activity, may compensate for this weakness, or more realistically, may be more promising targets for legal or political reform than the stock market.
\end{abstract}

Key words: block-holders, crony capitalism, investor protection, stakeholders.

\section{Introduction}

Corporate governance is generally defined as the set of processes, customs, policies, laws, and institutions affecting the way a corporation (or company) is directed, administered or controlled. It is a field in economics that investigates how to secure/motivate efficient management of corporations by the use of incentive mechanisms, such as contracts, organizational designs and legislation.

A broader definition of corporate governance would define it as the set of mechanisms that translate signals from product markets and input markets into firm behavior. This definition focuses on two elements the signals generated outside the firm and the control structures inside the firm to execute decisions based on these signals [1]. Such a definition is broader than the more traditional ones which tend to limit attention to the conflict between outside investors and top investors. It implies that control over a firm's course involves more than these two groups of actors. Despite having a theoretical tilt, this way of looking at corporate governance has important practical implications. It opens up the firm, and its management, to pressures other than that from shareholders. Further, it lays stress on the need to look at the issue of corporate governance in a wider context of product market competition and corporate links.

\section{Classification of Corporate Governance Models}

Corporate governance models may be classified into the "outsider" model and the "insider" model. In the "outsider" model the shareholders typically have no interest in managing the company and retain no relationship with the company except for their financial investments. Classic examples of countries that follow the outsider model are the U.S. and U.K. The outsider model is characterised by dispersed share ownership with large institutional shareholdings thereby altering the position of owners from and active to a passive agent. Hence, there is a "separation of ownership and control" and the individual interest of shareholders is thus subservient to that of managers who control the company. Interestingly, while India has borrowed much of its corporate governance principle from the U.S. and U.K., the model that is applicable in India is the "insider" model. The insider model is characterized by close knit groups of "insiders" who have a more long-term relationship with the company. The insiders, i.e. the controlling shareholders, are the single largest group of shareholders, while the remaining shares are held by institutions or individuals constituting the "public". In such a system the allegiance of the management is to the controlling shareholders, and it may well be that the two entities are the same. Therefore, what may work in an outsider model - where for instance "independent directors" may in fact be independent - does not translate that simply into the Indian context [2].

\section{Importance of Corporate Governance}

Consider the question, how important is corporate governance? For some, it is one of the most important policy issue, while others hold the opinion that its effects are secondary in nature. The extent to which corporate governance matters is ultimately an empirical question. LaPorta et al., (1997, 1998, and 1999a) [3] [4] 
raise a number of important questions concerning the interaction between law and finance, and more broadly about the role of institutions in economic development. Various other studies have analyzed the effects of legal rules protecting investors and the general quality of the legal system on, inter alia, - the development of the financial system [5], the impact of macro-economic shocks [6], the cost of capital [7], and corporate behavior and industrial growth [8] [9]. In many cases the explanatory power of the legal variables was found to be very strong thereby suggesting that the potential implications for policy are important. The main argument of LaPorta et al. is that when the legal framework offers inadequate protection to outside investors, entrepreneurs and original owners are forced to maintain large positions themselves to align their incentives with other shareholders [10]. Alternatively stated, countries with poor shareholder protection laws should have more concentrated ownership structures. LaPorta et al., find support for this hypothesis, and they argue that differences in investor protection have implications for corporate behavior and economic growth.

To make policy recommendations it is important to define the corporate governance problem of a particular country with regard to its institutions. In particular, the predominant corporate governance problem in a developing economy is likely to be different from that of a developed market economy [11]. These differences will affect the implementation of corporate governance recommendations.

Further, literature on corporate governance generally limit attention to control by the providers of capital and by equity holders. From a legal point of view, this restriction may be justified, because equity holders formally "own" the firm. The rationale for this is that, who owns should control. However, this argument is flawed because there is a big difference between "should" and does" [12]. Moreover, the difference relates not only to the conflict between top management and equity. Other groups, both inside and outside the firm, do exert significant influence on at least some decisions by the firm. These include the employees as a whole, higher and middle management, trade unions, firm-specific suppliers or buyers, other large firms which are not linked to the given firm by equity stakes, the public, and the government.

It is, therefore, proposed that the ambit of corporate governance should be broadened to include the problem of owner-controlled firms and large block-holders. Further, it should be generalized to a model of multilateral negotiations and influence-seeking among a number of different stakeholders [13]. In practice such a model should incorporate a number of checks and balances between various stakeholders and outside constraints, and must take into account how the political and legal system of a country affects this balance. Even if there is theoretical reason to believe that ownership with its incumbent benefits and costs lies with equity, this view is not widely held in most economies outside U.K. and U.S. of A.

\section{Corporate Governance and Developing Economies}

The broader notion of corporate governance provides scope for a better understanding of other economies, and in particular the developing economies, wherein anonymous stock markets are not likely to induce the necessary corporate restructuring and entrepreneurial activity. Further, it points towards other mechanisms that may compensate for this weakness (e.g. product market competition, labor market activity, peer pressure) or may be more promising targets for political or legal reform than the stock market.

This broader perspective suggests that corporate governance should not remain isolated from product and labor markets, the role of suppliers, employees, management networks, and the bodies of law that affect their workings and interactions, such as labor laws or competition law.

The interaction between corporate governance arrangements and the political system is another aspect that is generally over-looked. It may be argued that "crony capitalism" is a much more important problem in most developing countries than the protection of minority share-holders [14]. This is so mainly because dominant family owners of business groups are politically influential and are often successful in influencing legislation and regulation. Under such circum-stances it could well be that mere policy recommendations to change these rules may not be sufficient.

The above definition of corporate governance suggests that there are numerous channels through which signals from input and product markets may affect investment decisions. Hence the strength of these signals assume importance. For example, more competitive the product markets and stronger the bargaining power of suppliers, the more likely they are to influence the firm's behavior. However, if the controlling owner or the management is shielded from these pressures, the intensity of the signals may be rendered inconsequential. Under these conditions the legal framework would have to perform the twin tasks of reinforcing the signals and improving the mechanism whereby these signals are channeled into investment decisions.

\section{Some Implications for Developing Economies}

In most developing countries ownership and control of firms is strongly concentrated [15] [16]. Though the variation across countries is quite significant, apart from a few exceptions, firms have a controlling owner, family-controlled firms are important, and many large firms are members of business groups. The organisation 
of these business groups involves extensive cross-ownership, they are generally dominated by a controlling family, and often have good contacts in the government (for the case of India, see Bhagwati) [17].

As the group based corporate structure, in developing economies, is usually considered to be a response to missing capital market institutions, the relevance of shareholder protection laws for an assessment of the working of capital markets in such countries poses a problem. A comprehensive empirical study by [18], of business groups in emerging economies has found that in three out of the seven countries with large numbers of business groups (Indonesia, Taiwan and India), group membership has a statistically significant positive impact on firm's profitability, while its impact is near zero in the four other countries (Thailand, South Korea, Brazil and Chile). Hence these business groups though characterised by insider dominance, lack of accountability and transparency etc. at least do not seem to harm their own shareholders, given the environment they operate in.

The actual or potential role of external finance, in developing countries, is not as clear. Finance, internal or external, would be of help only when firms have access to profitable projects with low risk. However, the risk premium is high in many developing countries (weaknesses in investor protection, the rule of law, enforcement and transparency all contribute to this premium). In these circumstances, the business groups by channeling resources between the different firms in the group, relax the liquidity constraint at the firm level thus playing an important role. Here, a legal reform may be counterproductive if it disrupts these channels without establishing new reliable ones - which is quite likely to be the case at least in the short run [19].

\section{Conclusion}

Corporate governance was defined as the mechanisms translating signals from product and input markets into corporate behavior. The pressure generated by external investors was stated to be just one of these mechanisms. Other mechanisms discussed were monitoring by competitors, employees, suppliers, and intracorporate networks. The government can also influence the transmission of signals. The various pressures may push the corporation away from efficiency and profit-maximization. In such situations greater investor protection could serve as a welcome countervailing force.

The law has the potential to affect these tradeoffs and the ensuing costs and benefits. But these costs and benefits are multi-dimensional, and the law in general, and corporate law in particular, must be careful not to focus excessively on outside investors in the evaluation of these costs and benefits. Any statement about corporate governance and possible intervention through the legal system must, therefore, be preceded by careful analysis of the specific institutions of the country concerned.

\section{References}

[1]. E. Berglof and von Thadden, Ernst-Ludwig, 1999, The changing corporate governance paradigm: Implications for transition and developing countries, 1999, SITE Working Paper, Stockholm School of Economics and CEPR.

[2]. http://www.nfcgindia.org/pdf/ Guiding-Principles-of-CG.pdf, December 2014, Report of the Committee constituted by MCA to formulate a Policy Document on Corporate Governance.

[3]. R. LaPorta, F. Lopez-de-Silanes, A. Shleifer and R. Vishny, 1997; LaPorta, Rafael, Florencio Lopez-de-Silanes, A. Shleifer and R. Vishny, 1998; Law and Finance, Journal of Political Economy, 106, 1113-1155.

[4]. R. LaPorta, F. Lopez-de-Silanes, and A. Shleifer, Corporate ownership around the world, Journal of Finance, 54, 1999a, 471-517.

[5]. R. Levine, N. Loayza and T. Beck, Financial intermediation and growth: Causality and causes, manuscript, 1998, World Bank.

[6]. S. Johnson, P. Boone, A. Breach and E. Friedman, Corporate governance and the Asian financial crisis, 1998, manuscript, MIT.

[7]. D. Lombardo and M. Pagano, Legal determinants of the cost of equity capital, presented at the Journal of Financial Intermediation Symposium, 1999, Cornell University, Ithaca, New York.

[8]. R. LaPorta, F. Lopez-de-Silanes, and A. Shleifer, Agency problems and dividend policies around the world, 1999b, Journal of Finance.

[9]. R. Rajan, H. Servaes, and L. Zingales, The cost of diversity: diversification discount and inefficient investment, manuscript, 1998, GSB Chicago.

[10]. A. Shleifer, and R. Vishny, A survey of corporate governance, Journal of Finance 52, 1997, 737-783.

[11]. E. Berglof and von Thadden, Ernst-Ludwig, The changing corporate governance paradigm: Implications for transition and developing countries, 1999, SITE Working Paper, Stockholm School of Economics and CEPR.

[12]. E. Berglof and von Thadden, Ernst-Ludwig, The changing corporate governance paradigm: Implications for transition and developing countries, 1999, SITE Working Paper, Stockholm School of Economics and CEPR.

[13]. E. Berglof and von Thadden, Ernst-Ludwig, The changing corporate governance paradigm: Implications for transition and developing countries, 1999, SITE Working Paper, Stockholm School of Economics and CEPR.

[14]. E. Berglof and von Thadden, Ernst-Ludwig, 1999, The changing corporate governance paradigm: Implications for transition and developing countries, SITE Working Paper, Stockholm School of Economics and CEPR.

[15]. R. LaPorta, F. Lopez-de-Silanes, and A. Shleifer, Corporate ownership around the world, Journal of Finance, 54, 1999 a, $471-517$.

[16]. S. Claessen, S. Djankov and L.H. P. Long, Who controls east Asian corporations?, manuscript, 1998, The World Bank.

[17]. J. Bhagwati, India in transition: Freeing the economy, (Oxford, Clarendon Press, 1993).

[18]. T. Khanna, and J.W. Rivkin, Estimating the performance effects of networks in emerging markets, 1999, manuscript, Harvard University.

[19]. E. Berglof and von Thadden, Ernst-Ludwig, 1999, The changing corporate governance paradigm: Implications for transition and developing countries, SITE Working Paper, Stockholm School of Economics and CEPR. 